\title{
RIGHTS, INEQUALITY, AND AFRO-DESCENDANT HERITAGE IN BRAZIL
}

\author{
MARIA FERNANDA ESCALLÓN \\ University of Oregon \\ (iD https:/ / orcid.org/0000-0002-4241-3773
}

On our way to the Serra da Barriga, Renata, ${ }^{1}$ a hardworking public official from the Fundação Cultural Palmares (FCP) pointed at the mountain with its columns of gray smoke and charred vegetation. " "Look there, you see all those fires? It's a pity, a real shame.” In 2012, the Serra da Barriga in União dos Palmares, located in the northeastern state of Alagoas, suffered some of the most destructive wildfires in recent history. Located seventy-six kilometers from the state capital, Maceió, the Serra is home to one of Brazil's most iconic heritage sites, the Quilombo dos Palmares, famous for being one of the largest, longest-lasting maroon settlements in the country and home of the legendary military hero Zumbi (Freitas 1978; Schwartz 1987). Unlike other contemporary maroon settlements, or quilombos in Portuguese, where inhabitants make claims for recognition and land, Palmares is seen mostly as a historical site, as it was inhabited during the seventeenth century before being destroyed by Portuguese colonizers in 1694 (Anderson 1996). At its height, the settlement served as a refuge for fifteen thousand to twenty thousand Afro-descendant, indigenous, and other ethnic groups persecuted by the Portuguese colonizers (Funari 1996). In addition to serving as a refuge, Quilombo dos Palmares acquired fame for its political organization and fierce military defense (Orser 1998). 
Since the Portuguese destruction of the original settlement, land ownership around the Serra has proven extremely contentious (Cheney 2014). Such battles over land are common in areas of Brazil with quilombo settlements. Several indepth studies, led by the federal and state universities in Alagoas, have detailed the complex land tenure situation of the Serra. These studies note the presence of peasants in the Serra since at least the 1920s, long before the Afro-Brazilian activists' campaign to protect the area. In 1986 the Serra was declared a national heritage site, and as the state acquired ownership of the land, it ordered a number of local families occupying the site for decades to leave. ${ }^{3}$

According to some estimates, there were fourteen inhabitants in the Serra in 1986, but by 2011 the population had grown to nearly eighty people (Almeida 2011). Today the exact number of residents remains a source of debate, but most agree it includes at least sixteen families. Most of these residents identify as poor peasants, and they occasionally use ethnoracial ascriptions such as black, mestiço, moreno, or racially mixed.

In 2007 the state turned the quilombo site into a tourist park named Parque Memorial Quilombo dos Palmares. It is located at the top of the Serra da Barriga, and as the official website says, it "re-creates the environment of the República dos

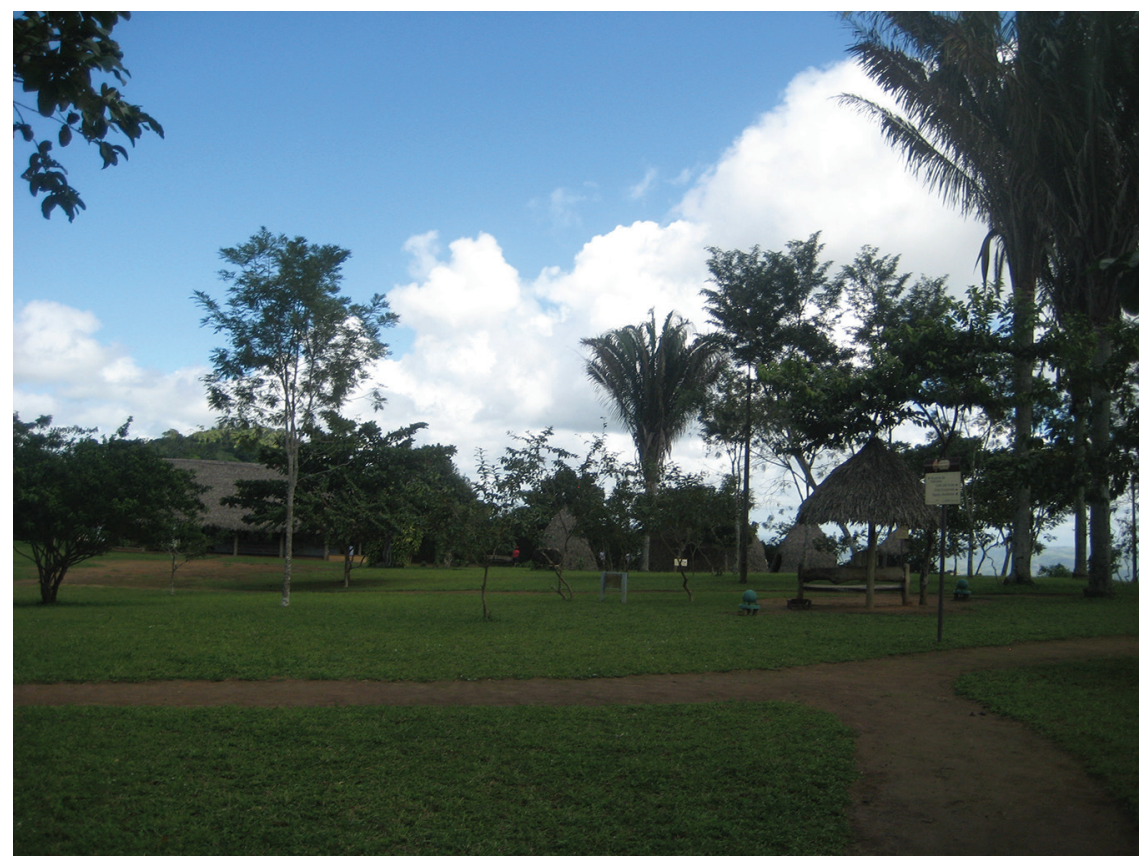

Figure 1. Panoramic view of Parque Memorial Quilombo dos Palmares, Alagoas, Brazil. Photo by Maria Fernanda Escallón. 
Palmares.” Though the park's touristic success is debatable, the importance of Quilombo dos Palmares as an icon of Brazilian culture continues to grow. For decades, annual celebrations in the park commemorating the death of Zumbi, the maroon leader of Palmares, have occurred every November 20, coinciding with National Black Consciousness Day, or Dia Nacional da Consciência Negra. In October 2017, the quilombo site was declared part of the cultural heritage of Mercosul. ${ }^{4}$ Today, as a result, many believe that Palmares should be declared a UNESCO World Heritage Site.

"Fires consume the vegetation of Serra da Barriga in União dos Palmares!" the national website Observatório Quilombola (2012) reported with alarm. Indeed, though smaller fires outside the heritage area had occurred before, the ones of 2012 were without precedent. For weeks, the fires remained the talk of the town, as newspapers continuously reported on the situation. The park rangers and some local officials believed the fires had resulted from arson. Park rangers accused the inhabitants of purposefully igniting the fires as retaliation for the rangers' strict control over their livelihood activities. Inhabitants claimed that rangers had started the fires to pressure residents out of the area. Given these many suspicions, one thing was clear: not just the Serra was under fire-there were livelihoods and history at stake.

In this article, I examine the paradoxical situation at Quilombo dos Palmares, where current residents help maintain the protected site but are also rendered as a threat to the park's historical and cultural heritage. This apparent contradiction derives from the fact that current inhabitants are not considered authentic descendants of the original maroons and are therefore deemed illegal occupants, or posseiros. As the local and national governments market Palmares's ethnoracially diverse past, the heritage park constitutes a violent exclusionary reality for its inhabitants. Although public media and academic research present Palmares as a unique historical landmark, it is also a place where common national dynamics take place, including the dispossession and surveillance of the rural poor. Indeed, despite its celebrated past, Palmares exemplifies the contradictory effect of Brazil's current multicultural regime: as the state defines its legitimate subjects of rights based on the standards of cultural difference, it often ends up reinforcing ethnoracial segregation (see Hale 2005; Wade 2013).

Focusing on the fires that ignited inside the park, I show that although Palmares is regarded as a national symbol of the inclusion of Afro-descendant history, it is also iconic for its insidious structures of exclusion of the rural poor. This situation sheds light on a pervasive yet often ignored dynamic throughout Latin America, where well-intended multicultural policies designed to empower ethnoracial 
minorities are implemented in a context of unequal access to financial and political resources. In this scenario, those groups who lack the resources that would make them legible to the state end up further segregated. Many of these groups find themselves in a double bind, as claiming an authentic ethnoracial identity is deemed opportunistic, while not claiming it renders them unintelligible to the state (Povinelli 2002; Hale 2005; Hooker 2008). This situation raises the question of how must disenfranchised groups self-identify in order to "deserve" (Hale 2005, 15) the right to live on their own land. The issue here is not whether the groups must self-identify as something - they must - but which categories they need to choose. More broadly, this case furthers our critical inquiry into multicultural citizenship and the political subjectivity expected from minorities, as the state envisions them as culturally defined subjects, rather than equal subjects of rights. The current discussion does not constitute a blanket critique of multiculturalism; rather, it means to expand our debates on how to proceed politically, because so many minorities still fall through the cracks of well-meaning ethnoracial policies. I argue that besides focusing our attention on rights that must be granted and protected, we need to better understand the local power dynamics at play, dynamics that ultimately enable minorities to fully exercise such rights.

My analysis provides an opportunity to examine the far-reaching effects of seemingly progressive neoliberal policies in Latin America, which include not just economic reforms but also the recognition of cultural rights, the strengthening of civil society, and support of intercultural equality. The contradictions experienced by the park's inhabitants highlight dynamics throughout the region that affect many disenfranchised communities in their struggle to find an authorized space for claims-making and a legible rhetoric under the current multicultural regime. In this essay, I describe multiculturalism not just as a normative approach aiming to redress unequal representation of minorities in culturally diverse nations (Taylor 1994). Rather, following Charles Hale (2005), I examine the place of multicultural reforms within the broader neoliberal political and economic transformations experienced throughout Latin America and use the concept of neoliberal multiculturalism to highlight the integral relationship between cultural recognition, collective rights, and neoliberal ideology.

\section{WHOSE PAST?}

"Welcome to the land of freedom," read the pamphlet I received on entering União dos Palmares. Indeed, this city is known in Brazil as a terra da liberdade (land of freedom), an explicit reference to the quilombo site where escaped slaves claimed 
their freedom from Portuguese colonizers. Despite inspiring pride in the historic accomplishments of the maroons, and providing a catchy slogan for local tourism, the land of freedom is a controversial label.

'It's interesting that here in 'the land of freedom,' we residents have no liberty. Clearly freedom is not for all," Lorenzo, one of the park's senior inhabitants, commented to me. Lorenzo, a longtime resident, is a member of one of the sixteen families living in the Serra. Many of these families have built small houses scattered throughout the hillside and report that they have been living there for more than three decades. ${ }^{5}$ Under constant threat, and with limited job opportunities, younger generations have left the park and moved to urban areas throughout Brazil. Of the inhabitants that remain inside the heritage site, some work in the park — formally or informally_ _ as janitors, tour guides, or food vendors, and most have regular interactions with tourists and public officials who visit the area. ${ }^{6}$

These inhabitants have no legal title to the lands they occupy, and they therefore live under constant threat of eviction because local administrators deem their presence illegal. In an effort to protect the landscape, the inhabitants have their daily activities closely monitored. They are forbidden from expanding their crops, and even permission to repair their houses is routinely denied. Most of their make-

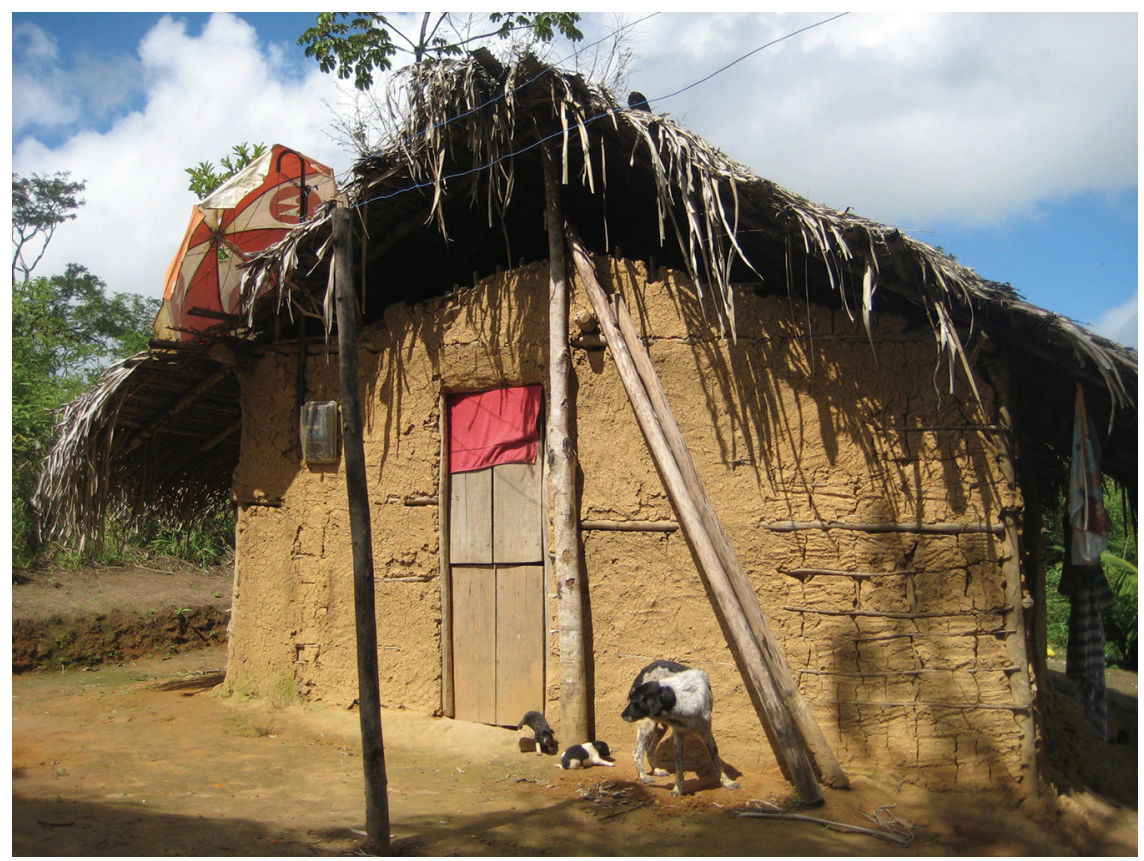

Figure 2. Serra da Barriga inhabitants' house. Photo by Maria Fernanda Escallón. 
shift houses are hardly standing, with portions of the walls and roofs falling apart. "Look, we barely have any walls, and after the rains it was even worse, but we are not allowed to rebuild," explained one of the inhabitants. "We don't even have toilets, as we can't dig holes in the ground," he timidly added. Indeed, as pointedly indicated by Lorenzo, although the park celebrates the freedom of its historical maroon inhabitants, it constantly surveils the activities of its current residents.

Between 2009 and 2012, I conducted field research in and around the Serra da Barriga, exploring the site's history and its heritage declaration process. I focused on how the precarious situation of the park's inhabitants reflects a broader paradox of Brazil's neoliberal multicultural regime, as poor rural workers' demands become unintelligible within a system that defines legitimate claims - and deserving claimants - on the basis of cultural difference (Hale 2005). I spoke to local bureaucrats, park rangers, residents, and Afro-Brazilian leaders to understand the place of Palmares in Brazil's political history. I lived in União dos Palmares (the closest urban center to the heritage site) and made frequent visits to the park and its surroundings where local residents live. I traveled around Brazil, interviewing scholars, politicians, and administrators who had conducted research in or been part of the design of the park. ${ }^{7}$

As my research advanced, it became clear that the quilombo's history was told in two very different ways: one highlighting its symbolic and political value as a historical landmark, the other emphasizing the precarious living conditions of its current residents. A good number of academics, activists, and bureaucrats enthusiastically recounted stories of the maroons' past and the quilombo's importance for Brazil. "Palmares is the biggest of its kind in the entire continent," a former FCP director told me. "Its history is so important, [because] it symbolizes a century of resistance. One hundred years! Palmares is where the Brazilian race was born . . . in Palmares people respected each other, they were free."

These accounts emphasize Palmares as an iconic site for Afro-Brazilian history and situate its heritage proclamation as a crucial transformation in Brazilian cultural politics. ${ }^{8}$ The enthusiasm surrounding Palmares also becomes evident in the prolific literature on this site, which includes hundreds of publications spanning a range of genres from academic works to children's stories. Some of the most well-known examples include the scholarship by Ernesto Ennes (1938), Arthur Ramos (1971), Décio Freitas (1978), Edison Carneiro (1988), and Flávio dos Santos Gomes (2005, 2011), which repeatedly reinterpreted the history of Palmares and the significance of Zumbi's life. ${ }^{9}$ Also widely known is the scholarship by Charles E. Orser and Pedro Paulo Funari (1992), Scott Joseph Allen (1995, 2001), Robert 
Nelson Anderson (1996), R. K. Kent (1996), and Pedro Paulo Funari and Aline Vieira Carvalho (2005b), as well as the chapters on Palmares in João José Reis and Flávio dos Santos Gomes's (1996) important compilation. ${ }^{10}$ For decades, written accounts of Palmares - many of which are based on colonial military excursions - have served as political inspiration and social critique. Indeed, a historiography of Palmares shows that the site's past has been interpreted in different ways, motivating, for instance, Marxist critiques of Brazilian society in the 1960s and 1970s (Almeida 2001) and serving as inspiration for a multicultural society by the 1990s (for more on Palmares's multiple interpretations, see Funari 2004).

Aside from the appeal that Palmares has in academic scholarship, many of the characters associated with the quilombo are national cultural icons, and images of Zumbi are widely reproduced in public buildings around Maceió, such as the airport. In União, a good number of shops like lottery-ticket stands and bakeries are named after Palmares. Similarly, countless activist groups and political movements invoke the quilombo and Zumbi's name.

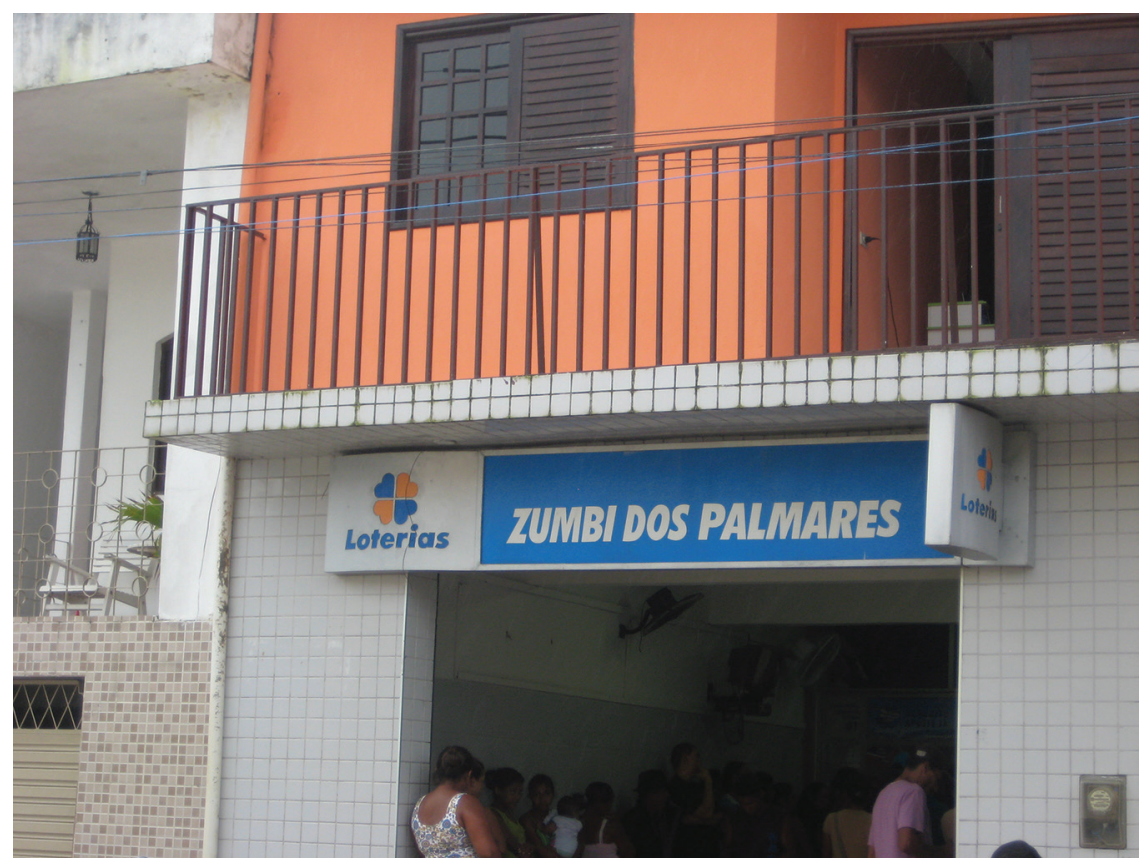

Figure 3. Zumbi is everywhere. Photo by Maria Fernanda Escallón.

The important value that Palmares holds also became evident during my interviews with government officials who saw the heritage park as União's untapped financial resource. As the city's tourism secretary said to me: 
The Serra is the single most important tourist attraction of the region. This area is part of the quilombo region and of tourist routes like the sugar or the freedom route. We hope that eight years from now this will be an important national tourist attraction and the Serra a key hub given its notable history. The quilombo is a symbol of freedom, there is no other place like this. Alagoas is very lucky.

In contrast to these enthusiastic visions of Palmares - as a cultural icon, a historical landmark, and a regional tourism engine-I heard stories of fear and violence from the park's residents. "Look, here is the stack of papers with the lawsuit against us," one elder resident told me as he handed me a heavy pile of documents. "Sixteen families have been accused . . . of environmental crimes," he explained with a trembling voice.

Although most could not read the documents themselves, they knew that blaming them for provoking the fires would facilitate their eviction. "We own this land, we are not vandals," said another inhabitant. "When we moved here there was nothing but sugarcane. I did not burn the Serra, I reforested it!” The first man lamented, "They stained our names, we have to clean them." Indeed, as a result of the lawsuit, many inhabitants were now prevented from working, applying for a bank loan, or receiving financial federal assistance. As they were subject to an ongoing criminal investigation, they could not apply for a national identification card, equivalent to a social security number in the United States, which is needed for everything from opening a bank account to applying for a job. After the fires, inhabitants reported that harassment by some of the park rangers had increased, meaning tighter controls over their cultivation techniques, farming plots, and daily activities.

After the declaration of Palmares as national heritage, the regional heritage office had tried to evict the residents. Park rangers, trained in environmental protection, were hired to monitor the inhabitants, making sure their houses and farming plots would not destroy the landscape. When one pieces together information from residents, land records, bureaucrats, and scholars, it appears that before the declaration, most of the Serra and its surroundings belonged to three wealthy and politically powerful landowners who leased a portion of their lots to sugarcane plantation workers. These renters were allowed to occupy and work the land, but not all received legal contract for their arrangements. When Palmares became a national heritage site in 1986, the heritage institute bought the lands and compensated the owners. Yet, only those with formal property rights received com- 
pensation, and renters were ordered to leave without any payment or alternative location. According to residents, the landowners' lawyers convinced the few individuals who had managed to get land property titles that if they registered their deeds or accepted any form of compensation, the government would take their lands away. When the period for registering land ended, sixteen families were left with no legal title, no financial compensation, and no place for resettlement. Many had no option but to stay in the Serra, overnight becoming illegal occupants of a federally owned heritage park.

"I bought this land more than twenty-three years ago," one of the park's inhabitants told me. "It belonged to Mr. Pinto. The government paid him, but he didn't pay a cent to me. We barely make a living, how was I supposed to pay for a lawyer?" Another resident interjected, "I did not invade the lands, I paid for them. How am I supposed to leave here without anything?" Tragically, there are no official records to verify these transactions. Rather than acknowledging the park residents' disadvantaged position as victims of fraud, unable to prove their claims, the state has rendered them illegal occupants.

\section{IDENTITY AND LAND IN A MULTICULTURAL PERSPECTIVE}

Since the 1980s many South American countries, including Brazil, have implemented a series of multicultural reforms to explicitly recognize pluriethnicity and guarantee group-based rights (Paschel and Sawyer 2008). These reforms have included the recognition of minorities' communal land rights, self-government, and access to ethno-educational programs (Hooker 2008). ${ }^{11}$ In Brazil, some of these dispositions were accompanied by the enactment of laws banning racial discrimination, the creation of affirmative action measures, or the establishment of federal institutions designed to combat racial discrimination (Hooker 2008, 284). The designation of Palmares as a national heritage site constitutes an integral part of these reforms.

Though the multicultural policies transformed the Latin American political landscape, in Brazil, many problems remain unresolved. Today, ethnoracial minorities struggle to find a persuasive narrative that legitimizes their claims for collective rights (Hooker 2008). More insidiously, the neoliberal multicultural reforms implemented so far have ended up reinforcing racial hierarchies and heightening the state's capacity to defuse political opposition (Hale 2005). As explored below, these reforms have also incited a pernicious backlash from powerful (and predominantly white) elites. The Palmares heritage park epitomizes these contradictory results. 
While in Palmares a quilombo is seen as a historical community of Africans and their descendants who escaped from slavery, across Brazil, comunidades remanescentes de quilombos designates a current, official category in which quilombolas (or contemporary self-ascribed maroon descendants) live. According to the Instituto Nacional de Colonização e Reforma Agrária (2018), quilombolas are ethnic groups, consisting predominately of blacks whose sense of identity is related to their land, kinship ties, and specific cultural traditions, as well as self-identify as descendants from formerly enslaved populations. ${ }^{12}$

After an unprecedented campaign led by Afro-Brazilian activists during the redrafting of a new constitution, in 1988 quilombola communities were granted the constitutional right to collectively own the lands they occupied as a form of reparation (Linhares 2004). To petition for a collective title, quilombola communities must be officially recognized by the government as legitimate descendants and then start a process of land titling. Since the introduction of these provisions, the number of communities claiming quilombola descent and communal property has been growing at a pace that is hard to fathom. Today there are an estimated 4,000 quilombola communities throughout the country, 3,311 of which have been officially certified as comunidades remanescentes de quilombos by the FCP, including 69 in the state of Alagoas. To date, there are more than 1,700 petitions for land titles across Brazil, and more than 975 of those in the northeast alone.

The cumbersome and lengthy procedures to petition for official quilombola status and land have kept many communities from claiming their communal property rights. Until March 2018, only one community had received its official deed in the state of Alagoas. An inefficient judiciary system, complicated administrative procedures, and strong political opposition from powerful landowners have slowed the titling process (Browne, Dana, and Shea 2010). Yet despite the hundreds of backlogged petitions, quilombola land titling has received much attention as one of the most widespread ethnoracial reparation projects in the world (Planas 2014b). As much as it has benefited some quilombola communities, this process has done nothing to change park residents' circumstances. Scholars, the citizens of the region, and public officials concur in their assessment that Serra residents are not quilombolas and should not be able to claim descent — and thus titles - from the historical quilombo. In my interviews with prominent black academics in Maceió, park rangers, and government officials, I repeatedly heard that the maroon settlement was destroyed by the end of the seventeenth century and that all its inhabitants were killed or dispersed to other regions. As asserted by a former FCP director, "the park's inhabitants are not original descendants from the quilombo. 
They are like everyone else. They do not self-identify as descendants; they invaded the lands. They are not quilombolas; they say so themselves." This idea reinforces the belief that there are no living descendants of Palmares and that those who currently live inside the park have no legitimate claim over this land or history.

Some interviewees mentioned that these residents had not occupied the site prior to the 1930s and therefore could not be direct descendants of the original maroons. The records of nearby universities corroborate these accounts, suggesting that park residents began occupying the region in the early twentieth century. Being seen as rural workers, as posseiros mestiços rather than remanescentes de quilombos, grants park inhabitants little political capital to fight for the lands on which they live. That they help maintain the heritage park seems almost irrelevant. As such, although Palmares's heritage declaration is meant to protect a valued historical site, it has also condemned its own caretakers to precarious living conditions. Ironically, the same tool that intends to protect Brazil's heritage has also become an instrument for dispossessing the rural poor.

The problem for these residents is not simply occupying federally owned lands deemed as heritage. Fundamentally, their struggle is of legibility under the current neoliberal multicultural regime, as the ways in which they identify themselves, namely as non-quilombola, renders them unintelligible to a system that grants collective rights based on cultural difference. Indeed, the language in which residents invoke their claims is one with which the FCP is not prepared to engage. During official meetings with the FCP, residents voiced their concerns in terms of their right to live and work on their own land. Rather than leveraging their ethnoracial identities, residents articulated their claims around their stolen territory. "We are asking for justice; I am a prisoner on my own land. We are surrounded by so much land, all belonging to Mr. Lyra, can the government buy some? My parents died waiting for their compensation, will I also die waiting?"

Finding the legitimating narrative to claim their rights proves difficult, precisely because the options available to them — via ethnic identity or racial discrimination - are effectively out of reach. Their lives as peasants are seen as insufficiently distinct to merit state protection (Hooker 2008), and any claim of quilombola descent is deemed as inauthentic. More insidiously, the state entirely disregards that powerful landowners took advantage of the residents, de facto justifying the inequalities created by Brazil's history of racialized slavery, white privilege, and the practice of sharecropping. As Juliet Hooker (2008, 287-88) asserts, in South America, there is still much resistance to drawing causal links between current inequalities experienced by disenfranchised groups, slavery, and racial dis- 
crimination. Leaving these issues unaddressed has ironically ended up reinforcing Brazil's institutionalized racism, which is what multicultural reforms were meant to dismantle.

By noting how the Palmares declaration has further disenfranchised its own caretakers, I am not implying that the site should not be protected or that the quilombola land restitution program should not exist. Quite the contrary: I think both are absolutely crucial. Nor am I implying that residents should be granted official quilombola status, as many park inhabitants do not identify as contemporary quilombolas, seeing themselves instead as rural workers with a legitimate claim to their lands. Instead, I want to highlight the paradoxical situation aggravated by the Palmares heritage declaration, where the protection of the histories of the oppressed ends up harming already vulnerable populations. In this way, Palmares offers a productive place to examine the value of alterity in Brazil, underscoring the political fragility of the mestiço rural poor whose histories are rendered as an illegitimate part of a heritage repackaged for tourist, academic, and political consumption.

The vulnerability experienced by these residents also highlights larger problems created by the current neoliberal multicultural regime. As the park residents' case shows, these policies inadvertently disempower a good portion of rural communities whose sense of identity does not align with the exact categories envisioned by the state. As such, the claims of poor rural mestiços, as well as their entire identity, are rendered ineligible within a multicultural national paradigm that presents minorities as coherent bounded groups who possess distinct culture and heritage. ${ }^{13}$

Critiques of multiculturalism have long explored how vulnerable individuals within minority groups may be further disenfranchised by the same policies designed to empower them. Feminist critiques of multiculturalism, for instance, hold that the protection of minority populations may come at the expense of perpetuating forms of segregation of vulnerable members within those groups, such as women (Green 1994; Eisenberg and Spinner-Halev 2005). In my own research, I have found that not all members of minority groups benefit equally from multicultural policies (Escallón 2017). This situation not only illuminates the paradoxical way in which identity policies operate but also underscores the unequal values that different forms of alterity hold. As Peter Wade (2013) explains, although blackness and indigeneity have been similarly cast as historically disadvantaged identities eligible for bureaucratic attention, that has not necessarily been the case for populations seen as ethnoracially mixed. Multiculturalism, then, has become "the 
alibi that deflects attention away from the remaking of racial hierarchy, under the triumphant banner of its elimination" (Hale 2005, 24).

This observation is significant, as the process of receiving an official status as a quilombola, for instance, is not just a process of self-recognition: it also requires a good amount of political expertise and local lobbying. As such, the process of claiming quilombola status and land is intrinsically designed to favor those communities who have better access to the intellectual, political, and social networks to make this happen. Self-identification as a quilombola is not just an ethnoracial or cultural matter; it is heavily mediated by politics and enabled by networks of power and financial means (see French 2009). By this I am not saying that only powerful communities have been granted recognition or lands. Indeed, many official quilombola groups live under conditions of extreme poverty. Rather, I am suggesting that at some point these communities leveraged the necessary connections, knowledge, and political expertise to support their claims.

Noting the limitations of multicultural policies is important because even though critiques of this model abound in academia, the reality is that in Latin America, multiculturalism remains very popular. Despite academic backlash, for many governments and minority activists, the basic tenets of multiculturalism still stand. As such, these policies continue to be implemented following political ideals rather than long-term studies of such policies' effects. It is crucial to understand that although multiculturalism theoretically has the power to do good, it also comes at a price, a price generally paid by the most vulnerable individuals within minority groups.

We must tread this line of argument lightly, however. As I write, fierce opposition continues to grow against the quilombola land restitution program following the 2017 suspension of these provisions across Brazil. Vocal objections from powerful individuals (including members of the agro-industry, real estate businesses, and logging companies) have consolidated against the quilombola reparations program. Opponents believe that these policies provide land to opportunistic individuals who strategically identify as quilombolas, or that they are ineffective as they fail to improve the quality of life of those residing in black settlements (Kenny 2018).

Another strand of opposition to ethnoracially based reparations is also growing, arguing that Brazilians are too racially mixed, making reparations based on an individual's race or ethnicity illegitimate. The idea that racial discrimination does not exist in Brazil because everyone is racially mixed has a very long and toxic history in the country. This notion has painfully downplayed Brazil's pervasive racial 
tensions and inequalities (Twine 1998). More recently, with the implementation of state-sponsored ethnoracially based policies, opposition has become even more vocal. ${ }^{14}$ As documented by Wade (2013), geneticists have appeared in court arguing against color-based affirmative action policies, stating that it makes no sense - genetically speaking - to refer to a separate black race, thus making it inappropriate to have a racial category targeted for specific benefits.

This situation proves particularly harmful because the racial disparities in Brazil remain so stagnant. It is estimated that although black Brazilians compose nearly 50 percent of the population, they constitute roughly 70 percent of those living in extreme poverty (Ribando Seelke 2008), which includes fifty-eight thousand quilombola families (Rocha de Mello e Souza et al. 2012). Statistics reveal that Afro-Brazilians are the poorest, have the worst housing conditions, work in the lowest-paying jobs, and have the least amount of lands (Planas 2014a, 2014b). Indeed, Brazil's land distribution remains one of the most unequal in the world, with less than 4 percent of landowners controlling more than half the country's arable land (Wittman 2009). Reports from the 2006 Census of Agriculture, carried out by the Brazilian Institute of Geography and Statistics, calculate a national Gini index of 0.872 and of 0.871 in Alagoas, ${ }^{15}$ indicating a very high and unequal concentration of land ownership. As a result of decades of smallholdings' land expropriation and the extension of property rights by large (and predominantly white) landowners known as colonels, ${ }^{16}$ very few Afro-descendants, particularly in the northeast, have formal property rights.

I mention this newly empowered opposition to ethnoracial policies because in the context of Brazil's prevailing racial disparities, their beliefs still carry an inordinate amount of weight. The inequalities between black and white Brazilians underscore the need for effective positive discrimination policies along racial lines. The dangerous notion of Brazil's racial democracy has done much to prevent a thorough understanding of the country's profound inequalities and to correct slavery's long-term legacies. The wealth, health, education, and employment gaps experienced by black Brazilians closely follow color lines and have been extensively documented in academic scholarship (Reichmann 1999; Reiter 2009; Daniel and Haddow 2010). As I point to the detrimental consequences of multiculturalism, I must be careful that my own arguments are not conflated with those espoused by these opponents. My observations are not meant to delegitimize the struggles of minorities or the policies aimed at providing much-needed reparations. On the contrary, I seek to explain why multiculturalism's aims remain unfulfilled in an effort to guarantee a better alignment of cultural policies with social justice causes. 


\section{THE ILLUSION OF INCLUSIVE HERITAGE}

To understand how the park was being maintained and used, I visited the site regularly during my field research, on my own and accompanied by park rangers, residents, and local administrators. On some occasions, I joined school visits, paying particular attention to how students learned about the site's history. On others, I heard the interpretations of the quilombo's past as told by local tour guides. In Rio de Janeiro and Recife, I interviewed those involved in the park's early designs, including prominent leaders of the black rights movement from Alagoas and Pernambuco.

According to my interviewees, before the park materialized, no consensus existed on how to commemorate the history and culture of the Palmares maroons. Local bureaucrats envisioned a park that would draw tourism to the area. Black activists hoped to build a monument commemorating the heroic lives of the historical Palmarinos. Brazilian academics from Alagoas, for their part, wanted to create a learning center to teach visitors about the history of the maroons. After heated debates between public officials and the Afro-descendant leadership from the region, in the early 2000s the local administration decided to construct what was described as a "staged Quilombo villa" in the Serra. By 2007, the tourist park Parque Memorial Quilombo dos Palmares was finally inaugurated.

As discussed by Ana Carolina Lourenço Santos da Silva and Flávio Gomes (2013), the creation of the park and the enactment of the land laws protecting the area are significant not just because they preserve a historical site but also because they commemorate the lives of those who fought for their freedom. Many Brazilians see the park and its heritage designation as a way of creating a new national memory, one that builds on intangible symbols and not exclusively on material culture. As such, the heritage designation was intended as a political move to broaden the notion of national heritage, something particularly important during Brazil's democratization process. Indeed, when inscribed in the national heritage registry, Palmares was one of the few sites included from the Brazilian non-elite, as the list had, until then, traditionally consisted of built structures from white wealthy families (Funari and Carvalho 2005a; Arantes 2008).

The creation of a new national memory remains one of the park's fundamental functions. As mentioned above, the park is at the center of the Dia Nacional da Consciência Negra festivities in Alagoas. The park's official website, for instance, devotes an entire section to the November 20 celebrations, detailing the significance of the events in which nearly ten thousand visitors engage on arrival to União. The festivities taking place at the park hold great significance for black activists, 
Palmarinos, and park inhabitants, who enjoy the political attention and economic revenue derived from the events.

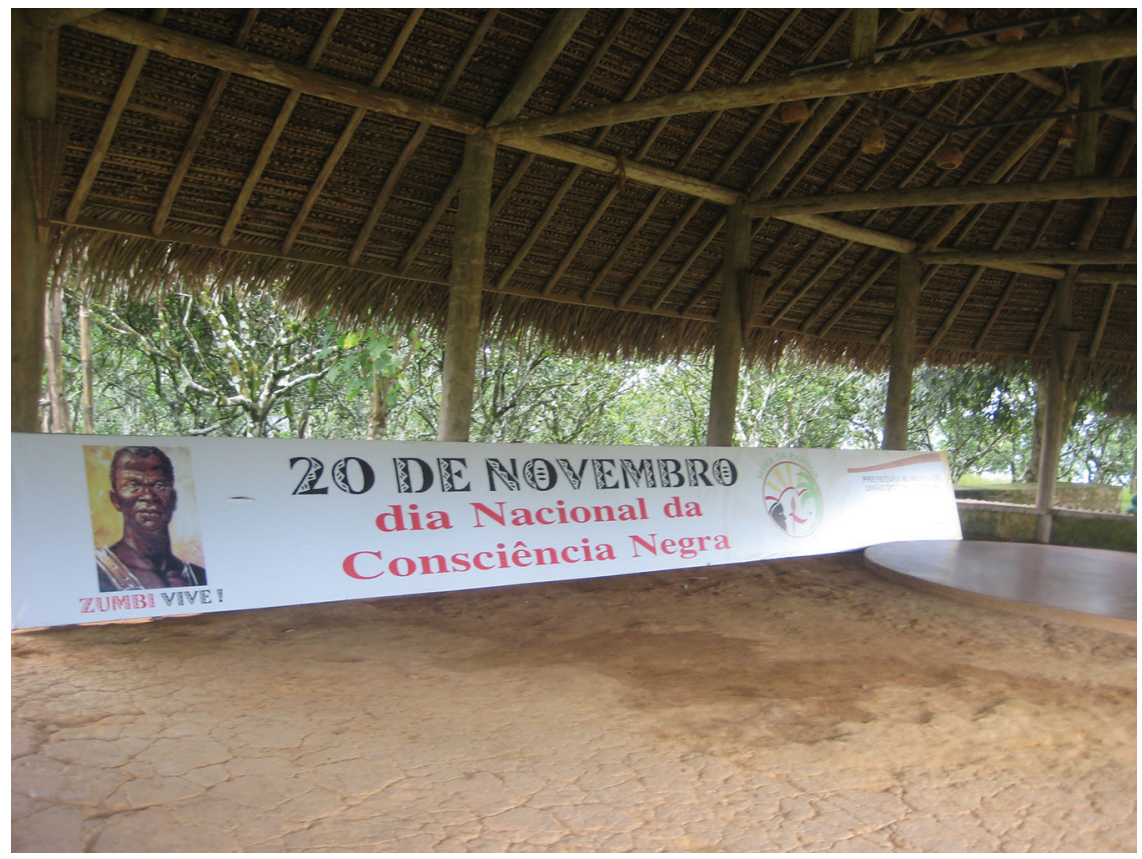

Figure 4. "20 de novembro" banner at Parque Memorial Quilombo dos Palmares. Photo by Maria Fernanda Escallón.

Despite the number of activities taking place in the Serra, neither the park's official website nor the scheduled celebrations explicitly include the park's caretakers. The heritage and history being celebrated gloss over the inhabitants' cultural practices, as well as their dire current situation. "In November they put 'makeup' on the Serra, on the whole situation with the park's inhabitants," a former local bureaucrat told me. Indeed, contrary to what occurs at other heritage sites around Brazil, where residents are expected to perform culture for mass tourist consumption (see Collins 2015; Smith 2016), in Palmares the inhabitants are rendered invisible and considered a threat to the park rather than either part of its history or part of its current life. The silence regarding the inhabitants, however, is full of meaning.

Fundamentally, though Palmares constitutes a site of celebration, it is also a symbolic battleground for park residents whose livelihoods are deemed as unworthy of protection. As such, while the heritage declaration broadly recognizes the history and culture of Afro-Brazilians and maroons, it uncomfortably sits side by 
side with the displacement of poor, rural, racially mixed farmers who identify as peasants, and occasionally as black, moreno, or mestiço, but who have no political leverage to claim for protection. While celebrating its multicultural and interethnic past, Palmares has trapped the park's inhabitants in an official recognition paradigm that simultaneously empowers and disenfranchises different segments of the black and ethnoracially mixed Brazilian population.

The lack of political leverage also stems from the way in which residents have organized themselves. As explained by an elder inhabitant, they once created a community-based association but did not succeed. By the time of my fieldwork, not all inhabitants saw themselves as part of a cohesive community, and there was no recognized leader. A few individuals, like Lorenzo, spoke in the name of the majority, but no formal community council existed. Without formal leadership, political stewardship has proven difficult. Though reports about their situation have sporadically appeared in local media, and national rural workers' movements remain active in Alagoas, ${ }^{17}$ there has been scant effective political support for residents.

As heritage declarations and identity-based policies expand in Brazil and elsewhere in Latin America, it is important to consider how well-meaning public recognition efforts continue to reproduce exclusion, even within the same groups they intend to protect. When poor rural workers cannot — or do not - claim ethnoracial distinction, they end up further segregated by a system that rewards ethnic lobbying and forces poor populations to demonstrate an authentic difference to be granted rights as equal citizens (Povinelli 2002). As such, while ethnoracial policies promote inclusion for some, they necessarily exacerbate inequality for others.

Palmares's situation is by no means unique to Brazil, or to other Latin American countries for that matter. Indeed, as examined by Anadelia A. Romo (2010), John F. Collins (2015), and Christen A. Smith (2016) in Pelourinho, the historical city center of Salvador de Bahia, the revitalization of this area as a national heritage site resulted in the forced removal of its residents. ${ }^{18}$ Much like Salvador, Palmares illustrates a cruel irony: the celebration of black culture in a historical site turned tourist attraction depends on the forceful repression of its own inhabitants. This reveals the state's two-pronged approach to blackness: exploiting its symbolic power while at the same time ensuring control over black and brown bodies (Smith 2016, 21). As such, Palmares serves as a metaphor for the nation writ large as the recognition of black heritage acts as a "deflecting shield, hiding the subtle yet exacting political and economic disenfranchisement of black Brazilians within a covert system of institutionalized racial discrimination" (Smith 2016, 111). 
As celebrations of black heritage in Palmares continue to ignore park residents' lives, it becomes clear that different constituencies have opposing ideas about what constitutes heritage. For park visitors and local bureaucrats, heritage is the past history of the maroons and the cultural practices of those who can ethnically, racially, or otherwise affiliate with them today. In contrast, for park residents, heritage is what they own and the lives they have created in and around the park. As one inhabitant asserted, "If we can't live, we can't work-and isn't this supposed to be our own heritage too?" A spokesman for the community posed the question a different way in a local newsletter, "Is this how they are preserving black culture?" (Barros 2015).

In light of the 2017 Mercosul heritage declaration, these clashing definitions of heritage resurfaced again. Newspapers and several online outlets reported the international recognition with much praise. In the words of the FCP president, Erivaldo Oliveira, "Mercosul's recognition is highly symbolic for the Black movement, it demonstrates respect for our ancestors who fought so hard for their freedom” (Rocha 2017). Similarly, Neide Oyá d'Oxum, a vocal advocate for the Serra's heritage preservation, proclaimed: "Besides generating employment, since tourism will increase, the Serra will be seen with different eyes, with eyes of love . . the Serra is a sanctuary of love, of faith, and resistance" (Rocha 2017). Despite this enthusiasm, the situation is not that cheerful for park residents. Rather than a sanctuary of love, the park has become a landscape of fear, one in which residents cannot repair their damaged homes, care for their crops, or live without surveillance. "Freedom for whom? Everything here is for the dead, for Zumbi, everyone is interested in history, nobody cares about the present. What freedom is that? Freedom to die?" pointedly asked a resident. Perhaps, as a renowned local historian told me, "The Serra is definitively important for some blacks, but not all blacks are as important for the Serra."

This statement underscores how the everyday violence experienced by the park's caretakers is connected to slavery's structural legacies. For one, the legal action taken against park residents demonstrates how they have unequal access to protection under the law, as they rapidly became subjects of criminal investigation for the Serra's fires, while the wealthy landowners' fraud was dismissed. The caretakers' experiences speak of broader patterns of violence and neglect against communities masked under the celebration of internationally sponsored heritage sites (see Smith 2016). Mercosul's support for Palmares proves significant as it globally legitimizes how under the current multicultural regime, only certain ethnoracial categories are deemed both legible and acceptable. ${ }^{19}$ Elevated as a regional heritage 
site, Palmares encapsulates a troubling situation in which "black inclusion into the national fabric follows a logic of permissibility that allows only those black bodies and spaces marked as acceptable to participate in the national project, and leaves the black masses at the margins" (Smith 2016, 6). As such, heritage has become, in Smith's $(2016,101)$ words, a "conditional privilege” for those who identify as quilombolas, granting them a provisional permission to participate in the nation as citizens. Without this conditional privilege granted by the heritage declaration and the current multicultural regime, however, park residents as rural peasants cannot be granted full citizenship rights.

\section{CONCLUSION: Identity in Light of Inequality}

The tension between recognizing ethnoracial identity and resolving inequality has been widely explored in academic scholarship for the past three decades (e.g., Fraser and Honneth 2003; Michaels 2006).The pendulum has moved from one extreme to the other, with some positing that diversity politics have displaced economic reparations, while others affirm that it is impossible to address inequality without considering identity first. I do not intend to resolve this long debate here, but rather wish to show how ethnoracial policies designed to combat inequality may have undesirable results by excluding already vulnerable populations. Rather than debating what should be done first-fixing economic inequality or recognizing ethnoracial difference-I show that when well-intended policies meant to benefit minorities are implemented in a context of unequal access to financial, political, and intellectual resources, those groups who are not already legible to the state end up further segregated.

Though park inhabitants claim the quilombo site as their home and heritage, they are peasants who do not use categories such as quilombola. As such, they are rendered invisible because the ways in which they identify themselves, and thus claim for their rights, fall outside the official canons recognized by the state (see also Brulotte 2009). My assessment is not a blanket critique of multicultural policies, or a rejection of any sort of reparation efforts. Much to the contrary, it means to continue our conversation on how to proceed politically, because so many remain sidelined by current ethnoracial policies. In the context of Brazil's massive ethnoracial inequality, which disproportionately affects blacks, quilombolas, indigenous, and other descendant populations, it is important to consider how the available alternatives to redress inequality may also perpetuate segregation.

The paradoxical situation of Palmares underlines how, as heritage- and ethnicity-based recognition policies have become an increasingly powerful mechanism 
for providing government protection for Afro-Brazilians, they, too, have acquired the disproportionate capacity to hurt the vulnerable and poor. Put simply, the more powerful this process becomes, the more power it also has to widen the gap between those who can benefit from recognition and those who cannot (Suassuna 2006). In Palmares, heritage is not just experienced as a means for power and inclusion for Afro-descendants but also as pain and segregation; this dimension is key to a more nuanced understanding of heritage histories often depicted through a singular lens.

As Brazil celebrates its black legacy, we must examine who has the powernot just the right - to make claims to land and state protection. The current understanding of heritage and the ethnically driven notion of blackness have prevented Brazilians from seeing the quilombo's paradox right in front of their eyes. As the Serra stood in flames, not a single news report talked about the danger posed to its inhabitants. Nobody mentioned the residents' impoverished living conditions or what the fires meant for their ever-shrinking territory. When visitors flock to the Serra during the November festivities, the celebrations ignore the inhabitants' cultural practices, as they are seen as unworthy of protection. While the Serra keeps receiving international attention, now as heritage of Mercosul, the park's residents continue to wonder why their own livelihoods are attacked in the name of protecting heritage and why their own cultural practices are not seen as Afro-Brazilian heritage at all. As such, the Palmares declaration protects two very different types of heritage: one of the historical maroons and their contemporary kin, and another of the structurally unequal system that inadvertently replicates the oppression it intends to dismantle (see Kenny 2018).

In recent years, a growing body of interdisciplinary research, including heritage scholarship, has pointed out the many ways in which current heritage policies negatively impact local communities. Much has been written on eviction and spatial cleansing (Bloch 2016; De Cesari and Dimova 2018), the uneven distribution of benefits (Breglia 2005; Escallón 2018) and cultural consumption and commodification (Chaves, Montenegro, and Zambrano 2010). The Palmares case, however, raises much broader theoretical reflections that go well beyond the critical examination of current heritage regimes. From the perspective of neoliberal multiculturalism, the predicaments of the park's inhabitants speak to how the state protects - or impinges on - the basic possibilities of existence of its own citizens. Indeed, the alternatives available to park residents with regard to how to live, work, and identify themselves as subjects of rights are effectively constrained by the way in which the state envisions ethnoracial minorities as cultural citizens. 
Neoliberalism informs not simply how heritage ought to be managed; it also molds a particular political subject (Coombe and Weiss 2015), expecting citizens to perform a specific form of subjectivity that exhibits "uncompromising autonomy of the individual, right-bearing, physically discrete, monied, market-driven, materially inviolate human subject" (Comaroff and Comaroff 1999, 3). The current neoliberal regime, which relies on self-empowered citizens, self-organized communities, and self-disciplined minorities that envision heritage as a resource (Coombe and Weiss 2015), further ostracizes park inhabitants who have not yet become the heritage subjects expected by the state. This situation illuminates the deeply paradoxical predicament of the neoliberal multicultural regime, as it theoretically embraces the plurality inherent in ethnoracial diversity, while it in practice closely restricts the type of political subjectivity individuals must embrace (Comaroff and Comaroff 1999; Englund 2006).

At stake here is not simply a reflection on how the current prominence accorded to heritage has devalued concern with actual forms of changing social life. More broadly, a discussion of citizenship is crucial, as the multicultural regime undermines alternative forms of political subjectivity that more closely align with the experiences shared by Brazilian peasants. As noted by Mary Lorena Kenny (2018, 100), in contemporary Brazil "the current social and spatial reality of rural life is, for the most part, invisible." Palmares has become idealized as a site of historical and political significance for Afro-Brazilians, even as a landscape of leisure for tourists. Yet, this image can only exist by denying its underlying history, connected to its inhabitants' struggle for housing, citizenship rights, and state protection.

More than a challenge to conventional approaches to heritage, I hope this discussion expands debates on whether multicultural policies use visibility as a form of subordinate inclusion, by providing recognition while leaving the structural tenets of racism intact. While the Palmares heritage declaration theoretically protects the site, it downplays the multiple layers of violence experienced by the heritage caretakers: individually, as a constant surveillance of livelihood activities, and structurally, as unequal protection under the law. Although the quilombola policies and Palmares heritage recognition have arguably benefited many black communities throughout Brazil, a crucial debate remains to be had on why impoverished Brazilians must claim difference to be treated as equal, and, importantly, on why this burden is imposed on the poor.

Turning a critical eye on multiculturalism's optimism, however, should not lead us to a wholesale rejection of heritage declarations, to delegitimize reparation policies, or to discourage communities from fighting for their rights. On the 
contrary, besides critical reflection on the rights needed to effectively protect minorities, we must identify the dynamics of power that enable Afro-descendants to successfully exercise those rights. I aim to reinstate attention to the local power dynamics at play in rural Brazil to encourage more informed political action and a grounded understanding of the limits of ethnoracial legislation as currently exercised. I note how heritage has become the means by which racialized histories of dispossession become sanitized stories of cultural difference. Yet beyond exposing multiculturalism's limits, I hope to expand our notion of reparative justice (see Mosquera Rosero-Labbé and Barcelos 2007), so that it protects not just the heritage of culturally defined subjects but also the lives of equal subjects of rights.

\section{ABSTRACT}

For the past thirty years, the Brazilian government has recognized dozens of sites and cultural practices of Afro-descendant groups as national heritage, including the historical maroon site Quilombo dos Palmares. As this site has gained international notoriety, academic research has focused on the value of this historical landmark for commemorating Afro-Brazilian heritage. This article looks to the ambiguous effects of such commemoration on contemporary people living in the area, some of whom are being forcefully evicted from the site in connection with its heritage status. The article addresses the vulnerability experienced by these residents, as it highlights broader issues associated with multicultural and heritage-recognition policies in Brazil. Specifically, I analyze the policies protecting contemporary maroon descendants and sites to reveal why Palmares residents making claims on their land and heritage fall outside of state recognition. I argue that as these policies have become an increasingly powerful mechanism for protecting Afro-Brazilian and minority groups, they have also acquired the capacity to hurt the most vulnerable individuals within these communities. Two very different types of heritage stand to be protected at Palmares: one of the historical maroons and their contemporary kin, and another of the structurally unequal system that inadvertently replicates the oppression it intends to dismantle. In the context of massive inequality that disproportionately affects blacks, maroon descendants, indigenous, and other minority populations in Brazil, it is critical to consider how political strategies for redressing ethnoracial inequality may also end up perpetuating segregation. [heritage; Afro-descendants; multiculturalism; quilombos; inequality, Brazil]

\section{RESUMO}

Ao longo dos últimos trinta anos, o governo brasileiro tem reconhecido como patrimônio cultural dezenas de espaços e práticas culturais de grupos afrodescendentes, entre estes, o espaço histórico do Quilombo dos Palmares. À medida que este local tem adquirido notoriedade histórica internacional, a pesquisa acadêmica tem priorizado 
a importância do local no que se refere à comemoração do patrimônio cultural afro-brasileiro. Meu trabalho analisa as consequências de tal reconhecimento patrimonial na vida de populações que residem atualmente nesta região, algumas das quais estão sendo expulsas à força do local, devido à declaratória deste como patrimônio cultural. Analiso também as vulnerabilidades experimentadas por tais populações, no contexto da problemática mais ampla das políticas multiculturais de reconhecimento do patrimônio no Brasil. Especificamente, examino as políticas de proteção aos quilombos e indivíduos quilombolas, e analiso como e por que o Estado não reconhece as reclamações de terras e patrimônio feitas pelos residentes de Palmares. Minha tese é que embora tais políticas venham sendo poderosos mecanismos de proteção aos grupos afro-brasileiros e às minorias, têm também adquirido uma capacidade desproporcional para prejudicar os indivíduos mais vulneráveis daquelas comunidades. Assim sendo, a declaração de Palmares oferece proteção a dois patrimônios muito distintos: um é dos quilombos históricos e seus descendentes contemporâneos, e outro, do sistema estruturalmente desigual que tem como consequência inesperada a replicação da mesma opressão que a própria política visava a desmantelar. Dentro do contexto de desigualdade massiva no Brasil, que prejudica desproporcionalmente as populações negras, os quilombolas, os indígenas e outras minorias, é de suma importância considerar como as políticas atuais que visam à reparação da desigualdade etnorracial também levam à perpetuação da segregação. [patrimônio; afrodescendentes; multiculturalismo; quilombos; desigualdade, Brasil]

\section{NOTES}

Acknowledgments I am deeply grateful to the journal's editors and anonymous reviewers, whose careful reading and insightful observations greatly improved this article. I express my gratitude to Erin Martineau, Clara Seligman Lewis, and Lauren Yapp, who reviewed earlier versions of this article, as well as to Karen Sotelino who helped with the Portuguese translation of the abstract. I am particularly indebted to George Lipsitz, Lynn Meskell, Barbara Voss, and Ian Hodder, who read and commented on preliminary versions of this essay. Some of the arguments I make in this article were first presented at the 2017 annual meeting of the American Anthropological Association. I am grateful to the panel organizers and attendees for their insights and suggestions. Special thanks to all my interviewees during my field research in Brazil, in particular to the local park residents and heritage managers who patiently and lovingly shared their knowledge with me. This research was supported by numerous centers, programs, and institutions inside and outside Stanford University, the University of California, Santa Barbara, and the University of Oregon. The field research phase was supported by the Social Sciences Research Council.

1. All interviewees' names, except those of public figures, have been changed. All translations from Portuguese are by the author.

2. The FCP is the public institution responsible for promoting and preserving Afro-Brazilian art and culture. It has regional offices across Brazil; the office in União dos Palmares manages the Palmares heritage park.

3. The Quilombo dos Palmares and the Serra da Barriga were legally protected long before Brazil had laws regulating intangible heritage. These protections were designed with tangible heritage in mind, although they were meant to recognize Brazil's black culture more broadly (Santos da Silva and Gomes 2013). The specific instrument protecting the Serra is called a tombamento; for a detailed analysis of tombamentos, see Fonseca (1997). 
The Serra was also declared a historic site in 1978 and a national monument in 1988. Santos da Silva and Gomes (2013) provide detailed accounts of the area's legal protection and its political implications. The shifting titles applied to the Serra and the Quilombo dos Palmares reveal how black culture became increasingly valuable not just in places of historical significance or as a relic of the past, but also as part of a politicized contemporary heritage.

4. Mercosul is a customs union and subregional Latin American trading bloc that uses culture as a way to strengthen regional integration. Mercosul's heritage declarations are one of the efforts advanced after the 1996 adoption of its Cultural Integration Protocol, which institutionalized the protection of the region's culturally diverse heritage (Dumont 2010).

5. See Correia (2016) for a detailed description of the park's residents.

6. Some residents are paid as employees, while others have created goods and services for visitors on their own.

7. Between 2009 and 2012, I conducted a multisited ethnography with national, regional, and local bureaucrats, academics, heritage professionals, local activists, community members, NGO staff, and tourists in Recife, Maceió, Campinas, Rio de Janeiro, Brasilia, and União dos Palmares. My research involved a combination of participant observation, semistructured interviews, open-ended conversations, and archival analysis. I conducted interviews in dozens of public and private institutions such as the Instituto Nacional de Colonização e Reforma Agrária, Instituto do Patrimônio Histórico e Artístico Nacional, Secretaria de Políticas de Promoção da Igualdade Racial, Ministério da Cultura, Secretaria Municipal de Cultura de União dos Palmares, and Secretaria de Estado da Cultura de Alagoas, among others. As a participant observer, I not only observed dayto-day activities in the Palmares Park but also participated in meetings about heritage, land rights, and political recognition of Afro-Brazilians. While living in União, I visited nearby officially recognized quilombola communities like Muquém.

8. For more on the political implications of the Palmares heritage declaration, see Santos da Silva and Gomes (2013).

9. For literature reviews of this historiography, see Gomes and Gesteira (2002) and Ruzemberg Gonzaga de Souza (2013).

10. The references provided are not exhaustive by any means. The literature on Palmares is vast, and the scholarship referenced here only serves as a sampling of well-known works. See, for instance, the extensive literature on Palmares by Pedro Paulo Funari.

11. Related policies include government decrees 10639/2003 and 11645/2008, which required Afro-Brazilian history to be taught in public schools; see Marcon and Brice Sogbossi (2007).

12. Since Brazil's ratification of the International Labor Organization Convention no. 169, the self-identification of a community as remanescente de quilombo is enough to seek official certification from the FCP.

13. See Correia (2016) for an extension of this argument, including criticism of the black rights movement Movimento Negro Unificado for contributing to the exclusion of park residents.

14. A similar discussion has accompanied the implementation of race-based quotas in public universities and in the public sector; see Telles and Paixão (2013).

15. The Gini index is a measure of inequality distribution, which gives a value between zero and one. Zero represents land equally shared between owners. One means that all available land is occupied by only one individual.

16. For an expanded discussion of coronelismo, see Carvalho (1997).

17. Direct support for the park residents from the Movimento dos Trabalhadores Rurais Sem Terra (MST), Comissão Pastoral da Terra, and Movimento de Libertação dos Sem Terra (among others) is inconsistent, even as some park inhabitants have joined MST encampments in Alagoas.

18. In the context of other quilombos, like Rio de Janeiro's Sacopã Quilombo or the Quilombo São Francisco do Paraguaçú in Bahia, quilombolas are thought of as opportunistic 
individuals, claiming lands that they have not traditionally occupied, let alone owned. Underlying these apparently legalistic debates is the doubt (from white elites) that historical reparation for enslaved descendants is morally justified.

19. While beyond the scope of this article, it is important to note that Mercosul's declaration exemplifies how, like other countries from the global South, Brazil uses the language of heritage to engage in a global politics of cultural diversity recognition.

\section{REFERENCES}

Allen, Scott Joseph

1995 "Africanisms, Mosaics, and Creativity: The Historical Archaeology of Palmares." Master's thesis, Brown University.

2001 "Zumbi nunca vai morrer: History, the Practice of Archaeology, and Race Politics in Brazil." PhD dissertation, Brown University.

Almeida, Luiz Sávio de

2001 "Quilombo e política." In Os Quilombos na Dinâmica Social do Brasil, edited by Clovis Moura, 89-102. Maceió, Brazil: EDUFAL.

2011 “Umas poucas palavras: o movimento negro em Alagoas.” Universidade Federal de Alagoas website, Notícias, March 16. Updated August 11, 2014. https://ufal. br/servidor/noticias/2011/03/umas-poucas-palavras-o-movimento-negro-emalagoas.

Anderson, Robert Nelson

1996 "The Quilombo of Palmares: A New Overview of a Maroon State in SeventeenthCentury Brazil." Journal of Latin American Studies 28, no. 3: 545-66. https://doi. org/10.1017/S0022216X00023889.

Arantes, Antonio A.

2008 "African-Brazilian Cultural References in National Heritage: Questions of Cultural Politics." Vibrant 5, no. 1: 20-33. http://www.vibrant.org.br/issues/v5n1/antonioa-arantes-african-brazilian-cultural-references-in-national-heritage.

Barros, Arísia

2015 "Fundação Palmares despeja moradores da Serra da Barriga, em AL, por telefone." Cada Minuto, Raízes da África, March 18. http://www.cadaminuto.com.br/ noticia/265818/2015/03/18/fundacao-palmares-despeja-moradores-da-serra-da-

Bloch, Natalia barriga-em-al-por-telefone.

2016 "Evicting Heritage: Spatial Cleansing and Cultural Legacy at the Hampi UNESCO Site in India." Critical Asian Studies 48, no. 4: 556-78. https://doi.org/10.1080/14 672715.2016.1224129.

Breglia, Lisa C.

2005 "Keeping World Heritage in the Family: A Genealogy of Maya Labour at Chichén Itzá." International Journal of Heritage Studies 11, no. 5: 385-98. https://doi. org/10.1080/13527250500337421.

Browne, Noah, Anne Dana, and Katherine Shea

2010 "Land Rights and Socio-Economic Development of Afro-Brazilian Communities." Duke Law Student Papers Series, July. https://scholarship.law.duke.edu/

Brulotte, Ronda studentpapers/4.

2009 “'Yo soy nativo de aquí: The Ambiguities of Race and Ethnicity in Oaxacan Craft Tourism." Journal of Latin American Anthropology 14, no. 2: 457-82. https://doi.

Carneiro, Edison org/10.1111/j.1935-4940.2009.01057.x

1988 O Quilombo de Palmares. São Paulo: Companhia Editora Nacional.

Carvalho, José Murilo de

1997 “Mandonismo, coronelismo, clientelismo: uma discussão conceitual." Dados 40, no. 2. https://doi.org/10.1590/S0011-52581997000200003. 
Chaves, Margarita, Mauricio Montenegro, and Marta Zambrano

2010 "Mercado, consumo, y patrimonialización cultural." Revista colombiana de antropología 46, no. 1: 7-26. https://www.icanh.gov.co/?idcategoria=6014.

Cheney, Glenn Alan

2014 Quilombo dos Palmares: Brazil's Lost Nation of Fugitive Slaves. Hanover, Conn.: New London Librarium.

Collins, John F.

2015 Revolt of the Saints: Memory and Redemption in the Twilight of Brazilian Racial Democracy. Durham, N.C.: Duke University Press.

Comaroff, John L., and Jean Comaroff

1999 "Introduction." In Civil Society and the Political Imagination in Africa: Critical Perspectives, edited by John L. Comaroff and Jean Comaroff, 1-43. Chicago: University of Chicago Press.

Coombe, Rosemary, and Lindsay Weiss

2015 "Neoliberalism, Heritage Regimes, and Cultural Rights." In Global Heritage: A Reader, edited by Lynn Meskell, 43-69. Malden, Mass.: Wiley.

Correia, Rosa Lucia da Silva

2016 "Como os nêgos dos Palmares: Uma nova história de resistência da Serra da Barriga, AL.” PhD dissertation, Universidade Federal do Pará. http://repositorio. ufpa.br/jspui/handle/2011/8954.

Daniel, G. Reginald, and Garry L. Haddow

2010 "Race, Class, and Power: The Politics of Multiraciality in Brazil." In Color Struck: Essays on Race and Ethnicity in Global Perspective, edited by Julius O. Adekunle and Hettie V. Williams, 269-310. Lanham, Md.: University Press of America.

De Cesari, Chiara, and Rozita Dimova

2018 "Heritage, Gentrification, Participation: Remaking Urban Landscapes in the Name of Culture and Historic Preservation." International Journal of Heritage Studies, September 18. https://doi.org/10.1080/13527258.2018.1512515.

Dumont, Juliette

2010 "La culture dans le cadre du MERCOSUR." La Revue des Médias, September 23. Updated February 6, 2019. https://larevuedesmedias.ina.fr/la-culture-dans-lecadre-du-mercosur.

Eisenberg, Avigail, and Jeff Spinner-Halev, eds.

2005 Minorities Within Minorities: Equality, Rights, and Diversity. New York: Cambridge University Press.

Englund, Harri

2006 Prisoners of Freedom: Human Rights and the African Poor. Berkeley: University of California Press.

Ennes, Ernesto

1938 As guerras nos Palmares: Subsídios para a sua história. São Paulo: Companhia Editora Nacional.

Escallón, Maria Fernanda

2017 "The Formation of Heritage Elites: Talking Rights and Practicing Privileges in an Afro-Colombian Community." In Heritage in Action: Making the Past in the Present, edited by Helaine Silverman, Emma Waterton, and Steve Watson, 63-74. New York: Springer.

2018 "Heritage, Land, Labor, and Competing Claims for Afro-Colombian Rights." International Journal of Cultural Property 25, no. 1: 59-83. https://doi.org/10.1017/ S0940739118000061.

Fonseca, Maria Cecília Londres

1997 O patrimônio em processo: Trajetória da política federal de preservação no Brasil. Rio de Janeiro: Editora UFRJ.

Fraser, Nancy, and Axel Honneth

2003 Redistribution or Recognition? A Political-Philosophical Exchange. Translated by Joel Golb, James Ingram, and Christiane Wilke. New York: Verso. 
Freitas, Décio

1978 Palmares: A guerra dos escravos. Rio de Janeiro: Graal.

French, Hoffman Jan

2009 Legalizing Identities: Becoming Black or Indian in Brazil's Northeast. Chapel Hill: University of North Carolina Press.

Funari, Pedro Paulo

1996 “A 'República de Palmares' e a arqueologia da Serra da Barriga.” Revista USP, no. 28: 6-13. https://doi.org/10.11606/issn.2316-9036.v0i28p6-13.

2004 "Conflicto e interpretación en Palmares." In Arqueología histórica en América del Sur: Los desafios del siglo XXI, edited by Pedro Paulo Funari and Andres Zarankin, 11-28. Bogotá: Ediciones Uniandes.

Funari, Pedro Paulo, and Aline Vieira Carvalho

2005a “O patrimônio em uma perspectiva crítica: O caso do Quilombo dos Palmares." Diálogos 9, no. 1: 33-48. http://periodicos.uem.br/ojs/index.php/Dialogos/ article/view/41416.

2005b Palmares, ontem e hoje. Rio de Janeiro: Jorge Zahar Editor.

Gomes, Flávio dos Santos

2005 Palmares: Escravidão e liberdade no Atlântico Sul. São Paulo: Editora Contexto.

2011 De olho em Zumbi dos Palmares: Histórias, símbolos, e memória social. São Paulo: Claro Enigma.

Gomes, Flávio dos Santos, and Heloísa Gesteira

2002 "Fontes neerlandesas e o Quilombo de Palmares na América Portuguesa do século XVII: Primeiras reflexões sobre representações e narrativas.” Américas 24, no. 4: $7-28$.

Green, Leslie

1994 "Internal Minorities and Their Rights." In Group Rights, edited by Judith Baker, 101-117. Toronto: University of Toronto Press.

Hale, Charles R.

2005 "Neoliberal Multiculturalism: The Remaking of Cultural Rights and Racial Dominance in Central America.” Political and Legal Anthropology Review 28, no. 1: 10-28. https://doi.org/10.1525/pol.2005.28.1.10.

Hooker, Juliet

2008 "Afro-Descendant Struggles for Collective Rights in Latin America: Between Race and Culture." Souls 10, no. 3: 279-91. https://doi.org/10.1080/ 10999940802347764.

Instituto Nacional de Colonização e Reforma Agrária

2018 “Quilombolas.” Program overview. http://www.incra.gov.br/estrutura-fundiaria/ quilombolas.

Kenny, Mary Lorena

2018 Deeply Rooted in the Present: Heritage, Memory, and Identity in the Brazilian Quilombos. Toronto: University of Toronto Press.

Kent, R. K.

1996 "Palmares: An African State in Brazil." In Maroon Societies: Rebel Slave Communities in the Americas, 3rd edition, edited by Richard Price, 170-90. Baltimore: Johns Hopkins University Press. Originally published in 1973.

Linhares, Luiz Fernando do Rosário

2004 “Kilombos of Brazil: Identity and Land Entitlement." Journal of Black Studies 34, no. 6: 817-37. https://doi.org/10.1177/0021934704264007.

Marcon, Frank, and Hippolyte Brice Sogbossi, eds.

2007 Estudos Africanos, história, e cultura Afro-Brasileira: Olhares sobre a lei 10.639/03. São Cristovão, Brazil: Editora Universidade Federal de Sergipe.

Michaels, Walter Benn

2006 The Trouble with Diversity: How We Learned to Love Identity and Ignore Inequality. New York: Metropolitan Books. 
Mosquera Rosero-Labbé, Claudia, and Luiz Claudio Barcelos, eds.

2007 Afro-Reparaciones: Memorias de la esclavitud y justicia reparativa para negros, Afrocolombianos, y raizales. Bogotá: Universidad Nacional de Colombia.

Observatório Quilombola

2012 "Incêndio de grandes proporções atinge Serra da Barriga." Notícia, April 25. http://koinonia.org.br/oq/2012/04/25/incendio-de-grandes-proporcoes-atinge-

Orser, Jr., Charles E. serra-da-barriga.

1998 "The Archaeology of the African Diaspora." Annual Review of Anthropology 27, no. 1: 63-82. https://doi.org/10.1146/annurev.anthro.27.1.63.

Orser, Jr., Charles E., and Pedro Paulo A. Funari

1992 "Pesquisa arqueológica inicial em Palmares." Estudos Ibero-Americanos 18, no. 2: 53-69. https://doi.org/10.15448/1980-864X.1992.2.29225.

Paschel, Tianna S., and Mark Q. Sawyer

2008 "Contesting Politics as Usual: Black Social Movements, Globalization, and Race Policy in Latin America." Souls 10, no. 3: 197-214. https://doi.

Planas, Roque org/10.1080/10999940802347707.

2014a "Afro-Brazilians Demand Slavery Reparations Because 'Poverty Has a Color.” Huffington Post, Latino Voices, August 26. Updated December 6, 2017. http:// www.huffingtonpost.com/2014/08/26/quilombos-brazil_n_5692077.html.

2014b "Brazil's 'Quilombo' Movement May Be the World's Largest Slavery Reparations Program." Huffington Post, Latino Voices, July 10. Updated December 6, 2017. http://www.huffingtonpost.com/2014/07/10/brazil-quilombos_n_5572236. html.

Povinelli, Elizabeth A.

2002 The Cunning of Recognition: Indigenous Alterities and the Making of Australian Multiculturalism. Durham, N.C.: Duke University Press.

Ramos, Arthur

1971 O negro na civilização brasileira. Rio de Janeiro: Livraria Editora Casa do Estudante do Brasil.

Reichmann, Rebecca Lynn, ed.

1999 Race in Contemporary Brazil: From Indifference to Inequality. University Park: Pennsylvania State University Press.

Reis, João José, and Flávio dos Santos Gomes, eds.

1996 Liberdade por um fio: História dos Quilombos no Brasil. São Paulo: Companhia das Letras.

Reiter, Bernd

2009 Negotiating Democracy in Brazil: The Politics of Exclusion. Boulder, Colo.: First Forum Press.

Ribando Seelke, Clare

2008 "Afro-Latinos in Latin America and Considerations for U.S. Policy." CRS Report

Rocha, Júlya for Congress. Washington, DC: Congressional Research Service.

2017 "Serra da Barriga atrai turismo e reconhecimento cultural para Alagoas." Agência Alagoas website, June 18. http://www.agenciaalagoas.al.gov.br/noticia/ item/16977-serra-da-barriga-atrai-turismo-e-reconhecimento-cultural-paraalagoas.

Rocha de Mello e Souza, Ana Flavia, Carla de Paiva Bezerra, Nilo Sérgio Nogueira, and Ronaldo Jorge Rodrigues de Oliveira

2012 "Programa Brasil Quilombola: Diagnóstico de ações realizadas.” Report. Brasília: Secretaria de Políticas de Promoção da Igualdade Racial. https://www.mdh.gov. $\mathrm{br/biblioteca/igualdade-racial/diagnostico-de-acoes-realizadas-programa-brasil-}$ quilombola/view. 
Romo, Anadelia A.

2010 Brazil's Living Museum: Race, Reform, and Tradition in Bahia. Chapel Hill: University of North Carolina Press.

Ruzemberg Gonzaga de Souza, Thyago

2013 "De Nina Rodrigues a Arthur Ramos: A reinvenção de Palmares nos 'estudos do negro.” Temporalidades 5, no. 2: 161-80. https://periodicos.ufmg.br/index.php/ temporalidades/article/view/5481.

Santos da Silva, Ana Carolina Lourenço, and Flávio Gomes

2013 "A lei 10.639 e a patrimonialização da cultura: Quilombos, Serra da Barriga, e Palmares. Primeiros percursos." Revista Teias 14, no. 34: 92-101. https://www.e-

Schwartz, Stuart B. publicacoes.uerj.br/index.php/revistateias/article/view/24349.

1987 "Mocambos, quilombos, e Palmares: A resistência escrava no Brasil colonial.” Estudos Econômicos 17: 61-88. https://www.revistas.usp.br/ee/article/view/157408.

Smith, Christen A.

2016 Afro-Paradise: Blackness, Violence, and Performance in Brazil. Urbana: University of Illinois Press.

Suassuna, Clara

2006 “Quilombo Muquém: Uma comunidade visível?” In Kulé-Kulé: Visibilidades negras, edited by Bruno César Cavalcanti, Clara Suassuna, and Rachel Rocha de Almeida Barros, 110-16. Maceió, Brazil: EDUFAL.

Taylor, Charles

1994 Multiculturalism: Examining the Politics of Recognition. Edited and introduced by Amy Gutmann. Princeton, N.J.: Princeton University Press.

Telles, Edward, and Marcelo Paixão

2013 "Affirmative Action in Brazil." LASA Forum 44, no. 2: 10-12. https://forum. lasaweb.org/past-issues/vol44-issue2.php.

Twine, France Winddance

1998 Racism in a Racial Democracy: The Maintenance of White Supremacy in Brazil. New Brunswick, N.J.: Rutgers University Press.

Wade, Peter

2013 "Blackness, Indigeneity, Multiculturalism, and Genomics in Brazil, Colombia and Mexico." Journal of Latin American Studies 45, no. 2: 205-233. https://doi.

Wittman, Hannah org/10.1017/S0022216X13000011.

2009 "Reframing Agrarian Citizenship: Land, Life, and Power in Brazil." Journal of Rural Studies 25, no. 1: 120-30. https://doi.org/10.1016/j.jrurstud.2008.07.002. 